\title{
Enclave deliberation and common-pool resources: an attempt to apply Civic Preference Forum on community gardening in Hungary
}

\author{
Fanni Bársony ${ }^{2}$ D $\cdot$ György Lengyel ${ }^{2}$ (D) Éva Perpék ${ }^{1,2}$ (D)
}

Published online: 3 August 2019

(C) The Author(s) 2019

\begin{abstract}
By analysing experiences of a Civic Preference Forum organised for community gardeners in Hungary in 2017, our paper's aim is twofold. We investigate if the Civic Preference Forum was an adequate format to enable discursive participation. Then we provide evidence on how this deliberative method can be applied on common-pool institution design gaining scientific knowledge about community gardening. Community gardeners, garden coordinators and experts were invited to the pilot Civic Preference Forum to share their experiences, problems, doubts, solutions, and opinions related to community gardening. First, the potential link between community gardening and deliberation is discussed and the method of Civic Preference Forum is introduced and placed among the deliberative and participative methods. Then by the lessons of the forum on community gardening it is demonstrated how the method can deliver insights for participants, decision-makers and academia. Participants' preferences and wishes are analysed by applying and testing the criteria of discourse quality analysis. It is argued that the Civic Preference Forum fulfilled the criteria of equal and open discursive participation and the analytic dimensions of evaluating the discourse worked well in the case of a Civic Preference Forum. Enclave deliberations based on proximity may differ from collective identity-based ones in terms of composition and implications. The first may result intra-group discursive equality, while the second may provide inter-group equality. Beside the methodological findings, the explored positive and negative side effects and limitations of the methods, the forum delivered new scientific knowledge on community gardens as common-pool resources, which helps to better understand the mechanisms in community projects. We learned that community gardeners' discourse was focused on such nodal themes as dependence and independence, monitoring and control, active and passive membership, equal and unequal participation, free riding and collective action, rules and norms of land cultivation and behaviour. Civic Preference Forum as a method enabled participants to clarify preferences, thematise problems and wishes as well as exchange ideas on possible solutions to them.
\end{abstract}

Keywords Enclave deliberation · Civic Preference Forum · Economic sociology · Community garden $\cdot$ Discursive participation $\cdot$ Discourse quality $\cdot$ Common-pool resource

This article was supported by the programme "Széchenyi 2020 EFOP-3.6.1-16-2016-00013". The authors would like to thank Ágnes Győri her valuable help during the research.

Extended author information available on the last page of the article 


\section{Introduction}

There is a growing interest both in deliberative methods and in common-pool resource management. The ambition of this paper is to link these methodological and substantive interests and check the methodological lessons of the application of a deliberative method on an emerging field of community gardening.

The foundation of deliberative democracy is the very process where public issues and alternative approaches are discussed and in certain cases, but not always resolutions are made based on consultations, forums and debates. Our research's focus is on the phenomenon of discursive participation,-issues related to open deliberation and discursive participation are problematised (Gastil 2000; Chambers 2003; Delli Carpini et al. 2004, p. 318). We investigate how discursive participation is realised through the method of Civic Preference Forum and how the forum can deliver knowledge on the problems and solutions related to community gardening. The discursive participation can be interpreted as a discussion and active participation through which participants can express and learn each other's preferences and opinions. In our case the exchange of opinions takes place in a regulated forum of like-minded people.

We argue that urban community gardens are common-pool resources and are worth to be linked with the idea of deliberation. In the first part, the potential link between community gardening and deliberation is discussed, then the position of Civic Preference Forum among the deliberative methods is located. After introducing the procedural characteristics of the forum, its substantive outcomes are highlighted. Here the focus is on the institutional design principles developed by Elinor Ostrom and whether the conditions necessary for the successful management of common-pool resources can be applied to the urban community gardens. Finally, the discourse quality of the forum and the potential positive and negative effects and limitations of the method will be evaluated.

\section{Urban community gardening and its deliberative potential}

In the international literature community gardens appear as multifunctional sites that can simultaneously fulfil goals related to food-provisioning, community building and environmental education (Firth et al. 2011; Russ et al. 2015; Torres et al. 2017). In some contexts where the gardens explicitly challenge the current patterns of food production and the usage of public space, they can be interpreted as sites for collective action and local activism (Nettle 2014). Even in less politicized contexts the gardens may serve as fields for practicing citizenship and participation (Ghose and Pettygrove 2014; Glover et al. 2005). Since the gardens operate as semi-public spaces where the physical infrastructure is collectively managed by the gardeners, beside food skills participants can learn the patterns of cooperation and community governance. Previous research (Glover et al. 2005) found that community gardening groups potentially effect the democratic values and practices of their own participants. But it is also presumed that participation in a community-based project can teach individuals how to overcome rational ignorance and participate in clarification of preferences and norm-setting. Community gardens usually operate in a low-hierarchic structure: gardeners are involved in directdecision making and there is high turn-over in leadership. Making collective decisions, 
practicing leadership roles may empower the members to play an active role in other issues of their localities.

According to the Putnamian idea (2000) the intensity of membership in voluntary associations is important to the development of the democratic culture. Hungary as well as the whole Central and Eastern European region is described as having a poorly developed civil society and weak civic participation (Kuti 2008). Therefore, it is particularly relevant to investigate how local level communities manage collective resources for recreational purposes and whether they have the potential to provide citizens with spaces where they could build trust towards each other and their local institutions.

Community gardens-just like in other countries of the region (Bitusiková 2016; Spilková 2017)—appeared in Hungary in the early 2010's (Bende and Nagy 2017). Our fieldwork prior to the Civic Preference Forum (Bársony 2017, 2018) confirmed that building interpersonal ties is an important motivation for the gardeners, however people with different motivations can participate in the same garden and self-fulfilment and communityrelated goals may be mixed and even conflicted within the groups of gardeners. Though explicit political motivations are not shared by all the gardeners, some participants attach symbolic meaning to their activities. These gardeners find it important to grow their own food, follow a sustainable lifestyle and participate in a voluntary project.

As for the proliferation and general knowledge of the gardens a recent nation-wide representative survey ${ }^{1}$ informed us that about $40 \%$ of the respondents said they heard about the concept of community gardens, but only $2 \%$ reported they know about a functioning garden in their proximity. Almost $17 \%$ would be open to be a member in a community garden and these respondents are almost equally distributed among the different types of settlements (capital, towns, villages).

Practically, there are no urban gardens in Hungary with a pure entrepreneurial character, neither gardens with the mission of serving marginalised people's needs. Most gardens are initiated and managed by urban citizens who at the first place see their involvement in community gardening as a hobby and recreational activity. Urban gardens do exist in smaller, medium sized Hungarian settlements as well, but the most significant and visible community gardening activity is concentrated in the capital city, Budapest. Most of the gardens are founded by the district-level local municipality, professional civil society organisations or informal civil groups (Bársony 2017, 2018).

Scientific inquiry concerning the gardens is also fuelled by the global trend and emergence of civic food networks (Renting et al. 2012). Community gardens as well as other forms of urban agriculture initiatives (e.g. community supported agriculture, food cooperatives, food swaps) can be understood as networks of citizens whose aim is to actively participate and regain control over food production and public spaces. Since civic food networks rely on voluntary, associational principles and participatory forms of self-management, civic food networks require not just engaged citizens but also an active involvement and collective governance by groups of citizens.

Collective governance mechanisms can be viewed through the lenses of Elinor Ostrom, whose scientific work was dealing with resources managed by close-knit communities typically in rural contexts. The basis of the Ostromian common-pool resources is a natural resource (e.g. forestry, fishery etc.) or a built physical infrastructure (e.g. irrigation system). These resources are typically managed by a closed group of people

\footnotetext{
1 Omnibus Survey of the Sociology Doctoral School of the Corvinus University of Budapest, January, $2019(\mathrm{~N}=1000)$. Data are available at the authors at request.
} 
who benefit from the resource individually and often make a living out of it (Ostrom 1990). Ostrom and her colleagues were conducting the institutional analysis of common resources and were curious what conditions are necessary to succeed at managing these. The suggested design principles to govern the resources in a sustainable way in a nutshell are the followings. The groups shall define clear boundaries. The governing rules shall fit the local conditions and those affected by the rules shall participate in modifying them. The rule-making rights of community members shall be respected by outside authorities and the community should be embedded in larger networks in case of larger common-pool resources. There must be a system for monitoring members' behaviour. Furthermore, graduated sanctions shall be designed against rule violators and low-cost means for dispute resolutions should be accessible (Ostrom 1990, pp. 88-101).

Urban community gardens can be interpreted as common-pool resources in contemporary urban contexts. The gardens are divided into individual plots where gardeners normally grow food for individual consumption. Almost all gardens contain however common areas which are cultivated jointly, plus there are tools, shared spaces (e.g. toolsheds), and services (e.g. electricity, water supply) which are used by the members collectively. The gardeners need to reach a consensus on how to cultivate the common areas plus how to maintain the common infrastructure such as paths, composting bins. Community gardens also require participation in a variety of tasks that need to be done with a certain regularity. Weekly minor tasks include picking up the trash, collecting compost and monthly responsibilities are like mowing, mulching paths, or maintaining infrastructure such as fences or water taps. The gardening communities need to find a way to motivate their members to participate in these tasks, plus the maintenance of the garden often requires collective decision-making. The location of the tap, the organisation of the tools such matters where the gardeners need to coordinate their actions. The close proximity of the individual plots also reinforces coordination: due to the easy spread of weeds, diseases and pesticides gardeners need to make sure that their actions cause no harms for their neighbours and that they define organic practices in the same way.

The community gardens are qualified resources in some respects: people are not involved in the collective action in the first place to sustain their lives and they may be heterogenous (Parker and Johansson 2011). By heterogeneity of the people it is meant that although there is a common goal and the group has clear boundaries, community gardeners may join the initiatives with different purposes. Motions may range from purely recreational and self-fulfilment reasons to more symbolic expressions of a lifestyle and world view. As a result, gardeners may attach different meanings and importance to the commonly managed garden and they may differ in terms of inclination to participate in the collective governance processes.

With the deliberative discussion we were aiming at collecting information about the participants' motivations, preferences, practices and wishes which are all relevant to explore the operation of community gardens. After inquiring about their motivations, we were curious about what claims gardeners express related to community gardening. If one accepts that community gardens are similarly functioning institutions to the Ostromian common-pool resources then these design principles are expected to appear in the experiences and wishes of the gardeners. The question is to what extent and with what kind of modifications are common-pool design principles present in community gardens, where the common-pool is not of vital importance but has to do with recreation and quality of life. 


\section{Deliberation, discursive participation and deliberative democracy}

Deliberation can be interpreted as a phenomenon related to a specific social model of democracy, or it is seen by others as a sort of sociological method (Lengyel et al. 2015). Deliberative methods however are fundamental to deliberative democracy (Habermas 1984; Fishkin 1995; Elster 1998; Gutmann and Thompson 2004; Fishkin and Luskin 2005; Dryzek 2000). Some scholars argue that representative and deliberative democracy models are opposing categories, whereas others argue that they may complement each other (Chambers 2003; Delli Carpini et al. 2004). Participants of deliberative forums can learn relevant facts, expert views and other opinions in a certain topic and thus become better informed, involved and active agents in the discussion. The deliberation process can result in enhanced responsiveness and responsibility of participants that serve the beneficiaries' needs and may have positive social impacts at the individual, community and societal level as well. But deliberative forums may have unintended consequences too. Due to a self-selection bias they may lead to information asymmetries. Knowledge gain and attitude changes of participants despite the expectation may prove to be short term phenomena only (Lengyel et al. 2015). In certain cases, a forced consensus instead of dynamic updating may lead to dissatisfaction of participants (Karpowitz and Mansbridge 2005). Widely popularized deliberative events may deflect public attention from deeper social and political problems, which could be added as a further point to the pathologies of deliberation (Stokes 1998).

Deliberation is different from interviews and large-scale surveys in that it provides participants with the opportunity to reflect on their own thoughts, and to encounter with the views of other participants (Burchardt 2014). The deliberative methods are aiming at disseminating information and expressing diverse opinions. Consequently, participants should be recruited from as broad economic, political and social background as possible. Deliberative consultations ideally provide the possibility for inclusion of the excluded social groups. Based on their analysis of civic forums Karpowitz and Raphael (2014) call this condition the equal participation principle. The practical evidences of the deliberative events however might contradict this theoretical principle: participants of deliberative consultations are often the members of those social groups which have higher social status and have the chance to represent the interests of their own groups in other forums. Instead of the opinions of the majority, often the voices of a powerful minority are channelled into decision making through the deliberative processes (Karolewski 2011).

Following the equal participation principle, it is not sufficient to ensure the representation of diverse social groups, it also needs to be secured that their insights will be considered with equal weight. There are initiatives particularly aiming at the excluded or smaller social groups and attempting to make their voices louder for the wider public. These principles are expressed in enclave deliberation. (Sunstein 2005; Karpowitz et al. 2009; Karpowitz and Raphael 2014, see also McKerrow 2015). Enclave deliberation of like-minded people can facilitate the involvement of group members of lower status and on aggregate level may expand the pool of arguments. On the other hand, due to reasons of group dynamics during enclave deliberation opinions may frequently shift toward an extreme pole. According to some arguments civic forums and deliberations in general should guarantee transparency and publicity (Raphael and Karpowitz 2013). These principles can best be served by involving the public into the process of deliberation. Through the internal and external communication of the processes, accountability, transparency will be provided, and the general public will also be informed about the content of the debated questions, dilemmas 
and problems. An indicator was designed to measure, evaluate and test the external communication related to the deliberation. The indicator is based on two categories: one is the argumentation which is to transfer the content of the deliberation, the other is the transparency which informs about the deliberative process. The argumentation should contain the conclusions based on the opinion of the participants, including the causalities, data, evidences, norms and the opposing arguments. If this information is openly accessible, the coherence and logic behind the arguments can be verified by researchers or other members of the public. The principle of transparency requires that the public is informed regarding who initiated, organised, managed the deliberative process and how this process was designed (selection criteria etc). It also needs to be documented what the purpose of the deliberation was, what expectations were set and how the deliberative process was evaluated and analysed, how the participants gave feedback on the event, whether they found the event to be fair and effective, if the event was organised in an authentic and responsible manner.

Jürg Steiner and his colleagues (Steenbergen et al. 2003; Steiner 2012) also developed a complex framework for the evaluation of discourses, they attempted to operationalise the quality of discourse in deliberation processes. Their tool, the Discourse Quality Index (DQI) relies on the Habermasian discourse ethics and emphasizes the process of argumentation and persuasion in the communicative action. According to Habermas and other theorists discourse ethics should fulfil the criteria of open participation, justification of assertations, participants should consider the common good, participants should treat each other, the demands and the other participants' counterarguments with respect, the deliberation should arrive at a consensus. Habermas involved the criteria of authenticity in his ethics, in the sense that every participant is transparent about its intentions. From the methodological point of view, it was considered as not directly observable, therefore this element was not involved in the DQI. Steenbergen et al. (2003) elaborated a measurement tool to test the quality of public discourses and they suggested "speech act" as a unit of analysis, particularly those parts of speeches which contain a demand, a proposal on decision that should be or should not be made.

In the following sections of the paper the method of the Civic Preference Forum will be located among the other deliberative and participative methods and then the results and the methodological considerations of a Civic Preference Forum on community gardening will be presented.

\section{The Civic Preference Forum among the deliberative methods}

Opinion formulation methods based on participation and conversation have various types. Researchers can choose from a wide variety of methods to gain the opinions of experts, leaders, activists and other stakeholders in issues of public interest. A new local or national legislation, decrees, modification, improvement or cancellations of a service and institutions of civic initiatives in the making are the potential cases.

The common element of these methods is to involve people in mediated deliberation on public issues. However the methods may differ according to aims, size, recruitment principle, duration and outcome (Karpowitz and Raphael 2014; Slocum 2003; Lengyel 2009; Tóth and Göncz 2009; Gastil and Levine 2005). ${ }^{2}$ There are methods (like Deliberative Poll

${ }^{2}$ There is a wide array of additional sources available on different participatory and deliberative methods, ranging from theoretical to practitioner orientations. Some examples: Abelson et al. (2003), Wakeford 
and Civic Dialogue) where the goal is to get stakeholders informed and involved in public issues and there is no need for a final decision. In others the aim is to produce a statement or decision based on consensus or vote (like in Consensus Conference or Citizens Jury). Some deliberative events may last for a couple of months (like Participatory Budgeting, or Citizens Assembly) while others (like the National Issues Forum or the World Cafe) deserve a few hours. In some methods the recruitment of the participants is based on random or quota sampling, while in other cases the event is open or the participation is based on a convenience sample. In some cases (like Town Meetings, National Issues Forum, Planning Cells) the number of participants may reach several hundreds and the event deserves serious financial resources, while others (like Focus Group or Civic Dialogue) consist of a dozen of participants.

The method of the Civic Preference Forum applied in this paper is to explore the common and/or policy-related demands, knowledge, opinions, experiences and preferences of the participants with the aim of informing the community and in case of need decision makers (Lengyel 2016). Civic Preference Forums are designed as follows. First, the team of researchers identify the theme of the forum and the problems related to it. Then the scenario of the discussion is elaborated. The population of stakeholders is determined, and the researchers take a 7-16 sample of it. The selected participants are invited, and an information brochure is attached to the invitation. In the meantime, 1-3 experts are identified by the researchers and invited to the forum with the request of sharing their knowledge and reflect on the comments and answering the questions posed by the participants during the forum. The deliberation is moderated by trained personnel who may be members of the research team. After the deliberative event participants are asked to give an individual written or oral feedback on the forum. The research team is evaluating and analysing the experiences and the results of the forum and if any demand is expressed by the participants the researchers forward the results to the stakeholders and the decision-makers. Civic Preference Forum belongs to the category of smaller and shorter deliberative methods and it doesn't deserve a final consensus of participants at the end of the discussion.

\section{The organisation and experiences of the Civic Preference Forum on community gardening}

\subsection{The organisation of the event}

We introduced a broad focus of the Civic Preference Forum from the content point of view, participants were invited to discuss their preferences and experiences. The goal of the Civic Preference Forum organised on community gardening was threefold: first, we aimed to provide participants of different community gardens in Hungary with a forum where they can clarify and discuss their needs and opinions, practices and solutions on community gardening. As a second goal, we wanted to test if Civic Preference Forum is an adequate format to enable discursive participation. Third, we intended to learn more about community gardens as common-pool resources and how do community gardeners settle their preferences and

Footnote 2 (continued)

(2001), Lawrence (2002), Stitt-Gohdes and Crews (2004), http://www.participatorymethods.org, https:// participedia.net, http://www.charretteinstitute.org/, https://www.participatorybudgeting.org, http://www.fao. org/docrep/006/T7838E/T7838E02.htm, etc. 
norms. In this paper we highlight some of the results with a focus on the Civic Preference Forum as a deliberative method (particularly, if the event fulfilled the criteria of discursive, equal and open participation) and how can it serve common-pool institutional design.

The forum took place in July 2017, but the preparations started already in March 2017. Following the necessary steps of organising a Civic Preference Forum, we worked out the scenario and prepared the information material that was later distributed among the participants. The research team defined the stakeholders, took a sample of them, and the experts were chosen and called upon. We defined the sample frame as the operating community gardens in Hungary. ${ }^{3}$ During the selection we aimed at having participants from community gardens of different types in terms of location (capital/other city; inner-city/suburban garden); institutional form and founder (municipality-founded, NGO-founded and informal civil group) and size (smaller gardens below 30 plots, bigger gardens up to $60+$ plots).

After the selection of the nine gardens we contacted the coordinators of the gardens and recruited the participants with their help. Community gardeners received the call for the participation through their coordinator and they could voluntarily apply to take part in the deliberation. Accordingly, our sample selection cannot be considered as random. The organisational arrangements are presented in detail in Table 1.

The participants received the information material ${ }^{4}$ prior to the forum and arrived at the event with some background knowledge both on the topic and the course of the deliberation. In the information material we referred to community gardening as "any area that is cultivated by a group of people with the aim of gardening." In the material we gave a general overview to the participants on community gardening including the history, development and the global spread of the gardens. The material also contained some information on the practical know-how on the formation and management of community gardens. The goals and design of Civic Preference Forums were also mentioned in the short leaflet. Prior to the Civic Preference Forum, the participants had been informed about the goals, course, data protection mechanisms and ethical considerations of the research and at the opening of the event they were reminded on these. The deliberation was moderated by two members of the research team. During the forum, the participants could share their thoughts and experiences with each other, and they also had the chance to listen to the invited experts and raise their questions to them. The more than $4 \mathrm{~h}$ long forum was video-recorded with the informed consent of the participants. After the deliberation a feedback questionnaire was distributed among the participants in which they were requested to evaluate and give some feedback on the forum in form of open-ended questions. Based on the participants' request, contact information of the participants have been shared so that the forum gave the floor for future communication and cooperation as well. As a symbolic acknowledgement, all the participants received a small package with a thank you letter, some present and certain but not considerable amount of money. The Urban Gardens Association published the information material on community gardening along with a report about the course and results of the Civic Preference Forum on their website. After the forum the research team started to evaluate and analyse the results of the discussion.

Sixteen community gardeners participated in the forum from nine different community gardens. Seven gardens operate in the capital, two in a smaller city in Fejér county,

\footnotetext{
${ }_{3}$ Data derived from the public database by KÉK (Contemporary Architecture Centre) http://kozossegik ertek.hu/kertek/.

4 The briefing material is available in Hungarian at: http://www.varosikertek.hu/wp-content/uploa ds/2017/08/Kozossegi_kertek_tajekoztato_BCE_2017-2.pdf.
} 
Table 1 The process of the Civic Preference Forum organised on community gardening Source: own summary based on Lengyel (2016)

\begin{tabular}{|c|c|c|c|c|}
\hline \multirow[t]{2}{*}{$\begin{array}{l}\text { Actors and research } \\
\text { phases }\end{array}$} & I. Planning phase & $\begin{array}{l}\text { II. Preparation } \\
\text { phase }\end{array}$ & III. Implementation & $\begin{array}{l}\text { IV. Feedback and } \\
\text { evaluation }\end{array}$ \\
\hline & March-May 2017 & June-July 2017 & July 2017 & August 2017-ongoing \\
\hline $\begin{array}{l}\text { Research team } \\
3 \text { Researchers from } \\
\text { the Corvinus } \\
\text { University of } \\
\text { Budapest }\end{array}$ & $\begin{array}{l}\text { Selection of the } \\
\text { topic of the } \\
\text { forum, working } \\
\text { out the scenario } \\
\text { of the forum }\end{array}$ & $\begin{array}{l}\text { Information mate- } \\
\text { rial on commu- } \\
\text { nity gardening } \\
\text { Sample selection } \\
\text { Involvement of } \\
\text { participants }\end{array}$ & Moderation & $\begin{array}{l}\text { Evaluation of experi- } \\
\text { ences and analysis } \\
\text { of the results }\end{array}$ \\
\hline $\begin{array}{l}\text { Participants } \\
\text { 16 Community } \\
\text { gardeners from } \\
7 \text { Budapest- and } \\
2 \text { Székesfehérvár } \\
\text { based gardens }\end{array}$ & $\begin{array}{l}\text { Not involved in this } \\
\text { phase }\end{array}$ & $\begin{array}{l}\text { Receiving the } \\
\text { briefing material }\end{array}$ & $\begin{array}{l}\text { Expressing opin- } \\
\text { ions and needs } \\
\text { Problems and solu- } \\
\text { tions } \\
\text { Questions to the } \\
\text { experts }\end{array}$ & $\begin{array}{l}\text { Filling out the feed- } \\
\text { back questionnaire }\end{array}$ \\
\hline $\begin{array}{l}\text { Experts } \\
2 \text { Experts } \\
\text { Urban Gardens } \\
\text { Association } \\
\text { Grundkert garden }\end{array}$ & $\begin{array}{l}\text { Not involved in this } \\
\text { phase }\end{array}$ & $\begin{array}{l}\text { Receiving the } \\
\text { briefing material }\end{array}$ & $\begin{array}{l}\text { Summary and } \\
\text { reflection of } \\
\text { the experiences } \\
\text { shared on the } \\
\text { forum; Answer } \\
\text { to the questions } \\
\text { posed by partici- } \\
\text { pants }\end{array}$ & $\begin{array}{l}\text { Dissemination of the } \\
\text { results of the forum }\end{array}$ \\
\hline
\end{tabular}

Székesfehérvár. Smaller gardens slightly outnumbered big ones. As we stated above, the sample is not random, and the most active gardeners are over-represented in it. All participants had secondary or higher education, they were typically managers, professionals or other white collars. Three out of four of them were females, their age varied between 32 and 73, around the average of 60; the median age was 68, that is, elderly people dominated the discussion (Table 2).

This event was designed as an enclave deliberation (Sunstein 2005): like-minded people discussed their needs and experiences of common interests. One qualification however should be added here: participants were like-minded but arrived from different community gardens.

Previous studies on deliberative events found that socio-demographic variables can have an impact on individuals' participation and on the discourse quality. Gerber (2015) highlighted the role of gender and found that women are less prone to speak up in the discussions (Karpowitz et al. 2012). Han et al. (2015) found that participants' age, gender and education make a difference in how actively engaged they are in the deliberative event. In our event we found that the setting of the forum is not unknown to the participants. During our fieldwork prior to the forum we witnessed assemblies organised by the individual gardens, participants mentioned during the forum as well that they discuss operational matters regularly in a similar format. Thus, one added value of the Civic Preference Forum was not its format rather its heterogeneous composition as nine different gardens were represented in it.

All the gardeners who previously applied for the forum appeared in the event. We found that this is due to that gardeners welcomed the idea of a common platform and discursive arena on community gardening. Beside this factor, the mobilisation of the gardeners was 
Table 2 Social characteristics of the participants Source: own compilation

\begin{tabular}{|c|c|c|c|c|c|}
\hline Participant & Community garden & Age & Gender & Highest education & Occupation \\
\hline Sz.Sz. & $\begin{array}{c}\text { Suburban garden } \\
\text { Budapest, big }\end{array}$ & 43 & Male & University & Mechanical engineer \\
\hline T.R.B. & $\begin{array}{c}\text { Suburban garden } \\
\text { Budapest, big }\end{array}$ & 51 & Female & University & Secondary school teacher \\
\hline SZ. I. I. & $\begin{array}{l}\text { Székesfehérvár } \\
\text { garden, small }\end{array}$ & 68 & Female & High school & Logistical manager \\
\hline M.E. & $\begin{array}{l}\text { Székesfehérvár } \\
\text { garden, small }\end{array}$ & 66 & Female & Secondary education & Forester \\
\hline Gy.E. & $\begin{array}{l}\text { Suburban garden } \\
\text { Budapest, small }\end{array}$ & 73 & Female & Secondary education & Financial assistant \\
\hline R.L. Sz. & $\begin{array}{l}\text { Suburban garden } \\
\text { Budapest, small }\end{array}$ & 40 & Female & Secondary school & Pharmacy assistant \\
\hline Z.R. & $\begin{array}{l}\text { Suburban garden } \\
\text { Budapest, small }\end{array}$ & $\mathrm{n} / \mathrm{a}$ & Female & $\mathrm{n} / \mathrm{a}$ & $\mathrm{n} / \mathrm{a}$ \\
\hline K.P. & $\begin{array}{l}\text { Suburban garden } \\
\text { Budapest, small }\end{array}$ & 70 & Female & High school & School financial manager \\
\hline N.G. & $\begin{array}{l}\text { Suburban garden } \\
\text { Budapest, small }\end{array}$ & 73 & Male & High school & Graduate engineer \\
\hline N.G.M. & $\begin{array}{l}\text { Suburban garden } \\
\text { Budapest, small }\end{array}$ & 69 & Female & Secondary school & Secretary \\
\hline T.J. & $\begin{array}{l}\text { Suburban garden } \\
\text { Budapest, small }\end{array}$ & 73 & Female & University & Loan officer \\
\hline B.A. & $\begin{array}{c}\text { Inner-city garden } \\
\text { Budapest, big }\end{array}$ & 32 & Female & University & Travel guide \\
\hline T.B. & $\begin{array}{c}\text { Inner-city garden } \\
\text { Budapest, big }\end{array}$ & 58 & Female & High school & Pre-school teacher \\
\hline N.G. & $\begin{array}{c}\text { Inner-city garden } \\
\text { Budapest, big }\end{array}$ & 70 & Female & Secondary education & Test operator \\
\hline L.L. & $\begin{array}{c}\text { Suburban garden } \\
\text { Budapest, big }\end{array}$ & 70 & Male & University & Building site manager \\
\hline L.A. & $\begin{array}{c}\text { Suburban garden } \\
\text { Budapest, big }\end{array}$ & $\mathrm{n} / \mathrm{a}$ & Male & University & Municipal department head \\
\hline R.G. expert & - & 50 & Male & University & Political scientist \\
\hline T.V. expert & - & 39 & Female & University & Community worker \\
\hline
\end{tabular}

Gardens were considered as "small" up to 30 and "big" above 30 plots (the biggest garden consists of 64 plots)

relatively easy thanks to the field experience of a member of the research team collected in community gardening sites.

The participating gardeners were first asked about their personal relations and motivations towards community gardening, and they were requested to introduce their community garden. By these introductions we gained new insights and confirmed the results of the previous explorations about the different institutional models of the gardens. As a second question, the participants of the forum were asked to mention the problems they experience and perceive regarding the daily operation of the gardens. This question was posed broadly, so that gardeners could refer to the most relevant and bothering problems they experienced. 
In this part of the forum we did not witness that any of the participants dominated the discussion. There were gardeners who expressed themselves more freely and contributed to the discussion more than some others. We attribute these differences to personal characteristics, generally we found that the atmosphere of the forum enabled participants to raise issues important to them. The circumstance that the discussion was organised with two facilitators was helpful in this respect.

The discussions about the problems was followed by the reflections of the two experts. One of them is an active gardener and a community development practitioner. Her comments were mainly focusing on the problems raised by the gardeners and internal, community-level challenges.

The other expert is the funder of one of the NGO-s that are patronising gardens. In his reflection, he connected the problem of responsibility for the community garden plot with the concepts of active and responsible citizenship and with this remark he attempted to move the discussion to a more abstract level. The interpretation of the gardens as places for active citizenship and democratic participation did not occur in the forum before. Furthermore, the expert was bringing new topics for discussion by problematizing the need for a central, capital city-or national level framework for community gardens. He was proposing a central budget as well as a central body for the management for all the existing gardens, and expressed the need that more gardens should be founded countrywide, and that community gardens should be considered and promoted by city planning. These claims were well received by the gardeners, they applauded and expressed their agreement with body language during the speech of the expert. The expert's thoughts however were not repeated or reflected on during the gardeners' individual comments which indicates to us that the expert's opinion was perceived by the gardens as something they do not question. The participants focused on issues that are coming from their daily experiences of governing the garden, and they could not connect to the higher level problems formulated by the expert. The setting of the forum by giving the floor to the participants first ensured that they raise the problems that directly affect them.

\subsection{The outcomes of the event from an Ostromian perspective}

Community gardens are often characterised in empirical case studies as open-access places (Bendt et al. 2013; McVey et al. 2018) which are managed by civil society groups, though open for the wider public. Community gardens in Hungary are not like the 'publicaccess gardens' introduced by some of these case studies. All the participants of our forum described the gardens as having clearly defined boundaries in terms of membership and access. Non-members are allowed to enter the gardens, but only occasionally and within the opening hours.

Norms and rules are essential for the governance of community gardens. Gardeners need to know what is expected from them when it comes to the maintenance of individual plots, common areas and infrastructure and the organisation of shared tasks. The forum gave an evidence that the community gardens operating in Budapest can differ in terms of how formal their rules are. The representatives of one inner-city garden expressed that they do not want to emphasize the rules and contracts to their members, because it would make the place less open and democratic. As a reflection, other participants from different gardens expressed that the rules and contracts are fundamental to engage people, and to balance individual and collective interests. 
It would be O.K if one person wanted to plant his Christmas tree in the garden. But what if 43 wanted to do the same? Then it would become a forest, so to keep the garden together, we need the rules. (Male gardener, coordinator, Budapest suburb garden)

Based on the forum and the preparatory fieldwork we found that despite their institutional differences (e.g. what is their relationship to the local municipality) the gardens operate among similar conditions and face similar challenges. However, differences in size of the group and the territory might require different contributions from members or different ways of coordinating tasks.

I was just listening that there are 18-20-25 members gardens. I can imagine that this rotary system is fitting that size. But we have 64 plots! We don't even know each other, it could not work for us. (Male gardener, Budapest, suburb garden)

As for community garden members' participation in rule-making, we found that in most cases where the municipality or a patronising NGO initiated the garden, gardeners accepted the rules as given and they did not consider modifying them. The representatives of the independent garden raised the issues whether rules are important or not. This discussion made almost every participant reflect on the role of rules. Apart from this exceptional garden the other gardeners who had no distinct opinion became convinced that the rules are important for the sustainable operation of the garden. Three gardeners reflected on the rules in their closing remarks, they also mentioned that they would consider the revision of the rules and contracts in their gardens.

Honestly, I have never thought before, that the set of rules are that important and that we have the possibility to renew them annually... (Female gardener, Budapest, suburb garden)

As it will be presented later in regards to the discourse quality of the deliberative discussion, relationship to the local municipality differ between the gardening communities. The gardens initiated by the municipality found it natural to be funded by the municipality, the gardeners from the NGO-funded gardens try to have a neutral and balanced relationship to the municipality, whereas the one independent garden established by an informal group of citizens tries not to have any connections to the local government. Despite the different attitudes, at some point of the discussion it was acknowledged by all the participants that neither the municipalities nor other authorities claim any rights to interfere in the internal operations and rules of the gardens.

The need for a functioning monitoring system occurred in the context of free riding. Since participation in the gardens is based on self-motivation, community gardeners can have different capacities and preferences to take part in the gardens' lives. Most of our participants perceived it as a problem, that beside an active core team, many gardeners do not contribute to the common tasks, and often neglect their individual plots causing a problem to the other gardeners. The gardeners of different communities shared practices and solutions they are experimenting with to overcome the problem of the unequal distribution of tasks. In one garden they use a rotary scheme where certain gardeners are responsible for the tasks on a weekly basis. In other gardens a coordination team is responsible for identifying the tasks and there are monthly occasions when all the gardeners are requested to contribute. In an other garden a certain day is appointed every week, which is the time to do the common tasks. There were clear demands expressed towards how the communities could strengthen their members' alignment and the fair 
distribution of common tasks. The gardens experiment with tools to encourage members to contribute, but they do not seem to dare to introduce systems that closely monitor members' behaviours. Gardening is a voluntary activity, and the gardens would like to keep the image of being free and open spaces. Many gardens fear to introduce monitoring systems because they do not want to establish obligations towards their members.

I would like to reach that everyone has eyes and notices what needs to be done... I don't want to instruct or monitor anyone, I wish it was like a family where everyone knows its duties and happy to do them. (Female gardener, coordinator, Budapest, suburb garden)

Monitoring systems in case of Ostrom's common-pool resources might be more legitimate, since there the members have stronger and more definite motivations and financial gains. There are two kinds of problems to be regulated in community gardens as it turned out from the discussion and from background interviews. One is the cultivation of the plot and taking care of the environment, while the other has to do with the behavioural code of the participants (i.e. activity in community programs). Backbiting, scandalization, gossiping as well as guiding and personal advice were widely applied concerning both types. More formal procedures of warning, voting, exclusion however happened only in the case of cultivation.

Community gardeners perceived the negligence of the individual plots to be the biggest rule violation. Not caring about his own plot detracts not only from the community spirit, but it can result in weeds and diseases that can affect others' plots and harvests. Every garden experienced this issue and graduated sanctions are written or unwritten rules everywhere. First, the abandoning members are warned orally, then they receive written notifications by email and if they show no change in their behaviour, gardeners can be sanctioned with exclusion. Gardeners and coordinators do not like to exclude members, the challenge for them is to learn whether the gardeners want to stop participation because of the lack of interest or their circumstances just do not allow them to temporarily look after their plot.

As to low-cost means for dispute resolutions smaller internal conflicts within the communities are perceived as normal by the gardeners, but they all were positive that they could handle conflicts. Social media platforms provide the gardeners with easy and cheap communication channels. Before implementing new assets gardeners often exchange ideas, arguments through their online channels. If there are disputes within the community, they might as well organise garden assemblies to discuss the conflictual issues. Open voting is a tool to decide about a certain issue.

She did not want to accept the exclusion from the garden, so we launched an assembly and everyone had to vote if she should be excluded or not. If someone could not come, they could vote online and finally we decided for her exclusion. (Female gardener, Budapest, suburb garden)

Embeddedness often referred to as the nested enterprise (Ostrom 2009) principle suggests that more complex common-pool resources are often linked into larger networks, because the complexity requires multiple layers of decision making. The gardens created by the same municipality or NGO are networked in the sense that they receive the same facilitation after the garden has been established and they have some opportunities to exchange good practices. Community garden policies as official programs at city or national level that would provide a framework for how to run a garden do not exist in Hungary. Associations, virtual networks for coordinating community gardens' activity are under construction. 
How to motivate the gardeners to participate and bear responsibilities in the shared tasks is a common challenge in the different community gardens represented in the Civic Preference Forum. Rotating work schedules, task forces, credit systems are different "push strategies" applied by the communities. In this respect, the gardeners expressed both during the forum and the feedback form that they gained valuable insights from each others' practices and they will be experimenting with new motivational strategies. Sharing practices as well as formal and informal rules can be considered as a learning and a potential improvement process because all the participants are free to embody the newly gained knowledge into their gardens' daily operation. By sharing contact information of the participants, future cooperation and exchange of views and rules may take place.

\subsection{The quality of discourse concerning wishes}

In the Civic Preference Forum community gardeners first were asked to share the problems and challenges they experience in their gardens. After the discussion the experts were reflecting on the gardeners' thoughts, and in the closing part all participants were invited to express and share their demands related to community gardening. Participants were requested to mention the wishes they would like to come true related to their community gardening activity. The moderators were not supposed to give specific instructions whether the expressed demands should relate to their own garden or whether more general claims are expected from them concerning the different scales (city or national level) of community gardening.

The event met the criteria of open participation and the analytic dimensions of discourse quality analysis (Steenbergen et al. 2003; Isernia and Fishkin 2014) proved to be relevant.

The gardeners could openly participate in the discourse without any major intended interruptions by other participants. If interruptions happened, these were mostly of supportive rather than destructive character. The expressed demands by the gardeners differed both in terms of justification and content. A group of gardeners expressed generic and abstract demands concerning community gardening:

I have three wishes: tolerance, good heartedness and money.

(Female gardener, Budapest, inner-city garden)

There is a need for good governance, good communication and [appropriate] channels. (Male gardener, Budapest, suburb garden)

Others' demands restricted to wishes regarding their own gardens' operations:

I wish we had a covered place where we and our guests could all sit and eat together. (Female gardener, Székesfehérvár garden)

I would like to have ... a permanent and long-lasting place so that we do not have to move anymore. (Female gardener, Budapest, inner-city garden)

Most gardens face these constraints because of the lack of financial resources. Land in most cases is subsidized by the municipality, but in case the garden does not want to cooperate with the local government it needs to be more self-reliant and face the challenge of the frequent move of the garden.

One of the experts expressed demands on more governmental support and a state and city level policy framework on the gardens and his speech resulted in comments made 
by other gardeners on these issues. The expert's visions were mostly accompanied by enthusiastic reactions (even applause) and some short supportive, confirmatory comments. At the same time, contrary to the expert's wishes, meaningful responses of the gardeners concerned a lower, municipality level. Some fears of an independent gardener were also expressed: she worried that municipality financing might weaken the gardens' freedom and independence. The second expert basically eased these fears and threats. The participants listed additional arguments and counterarguments on the role of municipalities so that the discourse became balanced in the end.

As for the content of justification of demands, even if the gardeners expressed a demand driven by their individual or narrow group interest, supposedly due to the communitarian character of the gardening initiatives, many of their comments contained arguments related to the common good, to the larger network of community gardeners or even to the whole society as beneficiaries of the gardens.

I wish we had more space so that we could invite more people, active people...to shape people's view and thinking on environmental and self-provisioning issues.

(Female gardener, Budapest, inner-city garden)

Participants in the forum showed respect both towards each other's demands and to the counterarguments. Despite the different experiences and models of operations among the gardens, participants were open to each other's practices. Gardeners expressed different views on how formal the set of rules in a garden should be, or how gardens shall ideally relate to the municipality. Ideas and arguments were exchanged though in soft manner, conflicting views were often set off with irony. The quick exchange below happened between two female gardeners from the same independent garden, one female expert and-although gender is not the dividing line here-two male participants, an expert and a gardener from a different garden:

- We keep ourselves far from the municipality. (Female gardener A, Budapest inner city)

- And we are happy about it. (Female gardener B, Budapest inner city)

- They are not that bad guys. (Male expert, community garden NGO)

- Of course not. (Female gardener A, Budapest inner city)

- Just as bad as dentists." (Male expert, community garden NGO)

- But we are not independent anymore. (Female gardener A, Budapest inner city)

- Why not? (Male expert, community garden NGO)

- If the garden is financed by the municipality... (Male gardener, Budapest suburb)

- We are not independent either, only we depend on ... [name of the company owning the garden's plots] (Female expert, Budapest inner city garden)

\subsection{Methodological considerations and limitations}

The deliberation introduced in this article both served as a tool to foster dialogue on an issue of public interest, and as a data collection tool to contribute to the sociological research of community gardening in Hungary. Our research interest was on exploring the field of community gardens as common-pool resources and testing the Civic Preference Forum in enclave deliberation. The deliberative forum served the explorative aim by 
providing a space for the gardeners to share their informed opinions and the potential collective positions, additionally, it helped to build networks between the different gardens and foster dialogue between the experts and the practitioners. In this sense besides being a research method, deliberation proved to be a particular "approach" to research (Burchardt 2014, p. 358).

Those coming from the countryside, from smaller, or suburban gardens and those who arrived from big or inner-city gardens had an equal say, so between-garden chances of preference clarification were balanced. Within-garden chances however were not balanced because passive gardeners were underrepresented in the forum. Their feelings toward community programs and preferences concerning the proper code of conduct most probably differ from that of the active core. (All that we learned in this respect emerged from the negative comments of the avant-garde participants.) Another limitation of the research is that it didn't include representatives of the municipalities and NGOs, which would deserve an alternative method. Enclave deliberation nevertheless could be applied in a special stage of setting the common-pool institutional design. It is a useful tool for transforming inclinations and feelings into preferences of the participants. If any of the like-minded stakeholders has a chance to participate that may be applied in a preliminary stage of common-pool resource design. Properly applied it may enrich the argument pool and may result singlepeakedness without moving toward an extreme pole.

It is hard to imagine a more peaceful activity than that of community gardeners' and a more tension-free event than the one devoted to their experiences concerning issues of recreation. However, the event at stake is not so innocent as it seems at the first glance due to theoretical and practical reasons.

Theoretical and methodological implications are threefold. The first is about the status of preferences. According to a marked position deliberation is a sort of discussion with the claim of changing preferences (Przeworski 1998). Though there are deliberative methods where the aim is to observe preference changes, there are others where not changing, but clarifying preferences is in the focus. Those who are familiar with the field would hardly deny that preferences are not "given". What empirical researchers meet with are more frequently than not sympathies, inclinations, aversions and opaque feelings. Even if there is a common aim and there are written obligations, these don't cover the range of everyday practices where both rules of land cultivation and community behavioural codes should be settled. Preferences in these cases should be dredged up from emotions which are in many cases inconsistent. Therefore, it is a legitimate aim, especially in case of problems having to do with collective identities to clarify preferences, instead of (or before) trying to change them. The second problem concerns decision making and vote. If one is interested in how rules and norms are settled in a community, primary information about the crystallisation of alternatives is more important than a decision reflecting the opinion of the majority. In this respect decision making and voting in an organised forum might be as unnecessary as in the case of a participatory observation of mushroom collectors (Fine 2001). Votes and decisions might be parts of the practice of community gardens, but they were not part of the deliberative event devoted to preferences of community gardeners. That leads to a third problem, that of the need of consensus as an outcome of the event. Civic Preference Forum does not need a conclusive consensus by design since the aim is to understand motives and preferences.

Potential practical difficulties arose from the fact that community gardens seemingly represented dispersed units of an emerging social movement and the event contributed to collective identity building of community gardeners. Hungarian party politics became extremely polarized in the previous decade and it had an impact on civic organizations. 
Associations devoted to recreational activities started to define themselves in terms of right- and left-wing ideologies (Lengyel and Ilonszki 2010). At the time of the Civic Preference Forum the mainstream political landscape was already dominated by illiberalism and some influential civic organisations dealing with issues of direct political relevance (like corruption, migration, freedom rights) got under pressure. Community gardens did not fall into this category, however the issues of independence or cooperation with authorities and-in Ostromian terms-getting embedded in broader common-pool resources became important in their case as well.

\section{Conclusion}

The forum was aiming to provide the participants of community gardens with a common platform to discuss their preferences and share the experiences of an activity which is relatively new to the urban context in Hungary. Accordingly, participants were rather interested in finding the commonalities and learning from each other. No matter which property regime or coordination style their gardens represent, the participants of the forum are all personally engaged in community gardening and therefore have a positive attitude towards the other gardens. It is also important to note, that despite the relative institutional diversity, the existing community gardens in Hungary have a rather similar social and ideological background. Lacking serious conflicting interests and arguments no demands were expressed by the participants to deliver any claims to the broader community or to any decision makers. Though one expert flashed some broader-city, state and even international-dimensions of urban agriculture as well as democratic values of community gardening, reactions, reasoning and discourse of the gardeners to this remained on the garden, municipality or local community level.

In terms of the motivations of community gardeners we identified two types: there are gardeners who are interested into produce healthy and cheap vegetable while others put more emphasis on community building. In our deliberative event recruitment was biased toward active members who consisted of the latter type. The more the gardeners are interested in building collective identity, the greater is the chance of getting closer to the type of enclave deliberation. The recruitment of participants has to do with the limits of the results as well. The research does not or does only partially inform about if there are and who hold opposite views about the phenomenon and what can be the potential counter-arguments against the gardens in the neighbourhood or among policy makers.

The Civic Preference Forum avoided extremization this time and it was mostly due to the quality of discourse and due to the fact that the group consisted of participants from dispersed groups. Potential extremization in our Civic Preference Forum coincides with funding and rulemaking regulations. Independence and cooperation are more emphasized by those who are more open toward gardeners' collective identity. Others who are not very much interested in collective programs take regulations and funding on behalf of the municipalities or NGOs.

Civic Preference Forums aim to understand the motives and preferences of participants. Our participants expressed the needs for cohesive communities and clarified their preferences in terms of rules, norms and behaviour. These needs were mostly in line with the institutional design principles developed by Elinor Ostrom. We found that the commonpool resources framework is a good starting point to analyse the operation of the urban communities of the gardeners. The gardeners expressed the need for clear group boundaries 
and agreed that rules and contracts are necessary to engage participants. We found that not all gardening communities require the same level of participation in rule making. Gardens initiated by external actors tend to rely on rules suggested by the municipality or the patronising NGO. The gardens generally fear to introduce monitoring systems, but they all apply graduated sanctions and cheap conflict resolution tools.

One of our goals was to test if Civic Preference Forum is an adequate format to enable discursive participation on community gardening. We found, that the Civic Preference Forum presented in this paper bears all the marks of the discursive participation (Delli Carpini et al. 2004). Through the discussions, exchange of experiences and hearing to the experts the community gardeners of the forum participated in the deliberation on a topic they are all affected by. The forum provided a new communication channel for the gardens and by exchanging contacts during the forum the participants gained new paths for further interactions (Raphael and Karpowitz 2013). The toolkit of discourse quality analysis was tested, and it proved to be applicable.

The forum provided participants of different community gardens in Hungary with a discursive arena where they could share and discuss their needs and opinions, practices and solutions on community gardening. The participants expressed during the event and in their written feedbacks that they found the opportunity of meeting and the knowledge sharing with the other gardeners useful. The forum provided the space for participants to learn about each other's practices, especially regarding the management of participation. Beside the learning outcomes, the evidence that participation, members-alignment mean a problem in every garden, assured participants that the challenges they face are not unique and there are diverse alternative tools to experiment with. Learning about the similarities supported the bonding and feeling of solidarity between the gardeners. At the end of the event gardeners of different communities agreed on to stay in contact and keep each other informed about issues of common interest so that to potentially cooperate and keep learning from each other.

The participants of the Civic Preference Forum were all committed community gardeners and activists who exchanged their ideas and experiences about their problems and solutions. We got knowledge on their motivations, how they think about the urban community gardens and through the gardens about the society, furthermore, the deliberative event helped participants to clarify their preferences regarding community gardening and guaranteed the equal participation of them which is an essential design element of common-pool resource institutions.

This time we did not intend to test if the legitim publicity is realised in the external communication of the event (Raphael and Karpowitz 2013; Karpowitz and Raphael 2014; McKerrow 2015). The documentation of the event however would make it possible and by doing so the analysis of the discourse quality of Civic Preference Forums could be improved. Another challenging purpose would be to examine the aftermaths (if any) of the forum in the everyday life of participating gardens and gardeners in terms of emerging communication paths, exchanging information, incorporated knowledge and/or practices, attitude changes, needs for further organised discussions.

Like-mindedness may characterise communities, where members know and frequently talk to each other, living in proximity. This is generally the case of community gardens and most common-pool resources. But like-mindedness could be observed among dispersed groups as well and this is also true on community gardens. The Civic Preference Forum presented above deals with this second type phenomena. 
An enclave deliberation of a close-knit community with careful design may provide equal voice to members of lower prestige in the community and may enrich the pool of arguments in one way or other: among others it may help to transform inconsistent feelings, hopes and doubts into preferences. However, during this clarification process the public mood may move toward extreme poles.

Enclave deliberation could be applied on like-minded but separated groups as well. In this case like-mindedness is not provided by social and physical proximity but by shared values and the formation of a collective identity. If it is so, the clarification of preferences concerning core issues is easier due to the sense of collective identity. The mood could be more tempered for the same reason and due to the fact that most participants don't know each other. Preferences concerning rules and norms are not settled in sharp debates because they had been evolved during the everyday practices of the groups. Enclave deliberation may serve as a forum of good practices in this respect. It may also contribute to the strengthening of collective identity and meaning-making of emerging social movements and pressure groups.

Enclave deliberation can be applied on both types of like-mindedness (one based more on proximity and the other on identity). If they succeed, the first can guarantee intra-group, while the second inter-group equality. Both might be relevant for common-pool resource designs, but they represent two different tracks and could be applied for different problems of institutional development. A Civic Preference Forum devoted to a particular gardening community to elaborate more on the governance, norm- and rule formations may enrich experiences concerning intra-group equality. The event presented above facilitated the communication of like-minded people belonging to dispersed groups.

Acknowledgements Open access funding provided by Corvinus University of Budapest (BCE).

Open Access This article is distributed under the terms of the Creative Commons Attribution 4.0 International License (http://creativecommons.org/licenses/by/4.0/), which permits unrestricted use, distribution, and reproduction in any medium, provided you give appropriate credit to the original author(s) and the source, provide a link to the Creative Commons license, and indicate if changes were made.

\section{References}

Abelson, J., Forest, P.-G., Eyles, J., Smith, P., Martin, E., Gauvin, F.-P.: Deliberation about deliberative methods: issues in the design and evaluation of public participation processes. Soc. Sci. Med. 57(2), 239-251 (2003)

Bársony, F.: Városi közösségi kertek Magyarországon mint a commons megnyilvánulásai (Urban community gardens as representations of the commons.) Manusript (2018)

Bársony, F.: Collective action in and beyond community gardens. Corvinus University of Budapest. Doctoral School of Sociology. Ph.D. Research Proposal. Manuscript (2017)

Bende, C., Nagy, G.: Effects of community gardens on local society: the case of two community gardens in Szeged. Belvedere Meridionale 28(3), 89-105 (2017)

Bendt, P., Barthel, S., Colding, J.: Civic greening and environmental learning in public-access community gardens in Berlin. Landscape Urban Plan. 109(1), 18-30 (2013)

Bitusiková, A.: Community gardening as a means to changing urban inhabitants and their space. Crit. Hous. Anal. 3(2), 33-42 (2016)

Burchardt, T.: Deliberative research as a tool to make value judgements. Qual. Res. 14(3), 353-370 (2014)

Chambers, S.: Deliberative democratic theory. Annu. Rev. Polit. Sci. 6, 307-326 (2003)

Delli Carpini, M.X., Cook, F.L., Jacobs, L.R.: Public deliberation, discursive participation, and citizen engagement: a review of the empirical literature. Annu. Rev. Polit. Sci. 7, 315-344 (2004)

Dryzek, J.S.: Deliberative Democracy and Beyond. Oxford University Press, Oxford (2000) 
Elster, J. (ed.): Deliberative Democracy. Cambridge Studies in the Theory of Democracy. Cambridge University Press, Cambridge (1998)

Fine, G.A.: Enacting norms: mushrooming and the culture of expectations and explanations. In: Hechter, M., Oppeinheimer, K.D. (eds.) Social Norms, pp. 139-164. Russell Sage Foundation, New York (2001)

Firth, C., Maye, D., Pearson, D.: Developing "community" in community gardens. Local Environ. 16(6), 555-568 (2011)

Fishkin, J.S.: The Voice of the People. Yale University Press, New Haven (1995)

Fishkin, J.S., Luskin, R.C.: Experimenting with a democratic ideal: deliberative polling and public opinion. Acta Polit. 40(3), 284-298 (2005)

Gastil, J.: By Popular Demand. University of California Press, Berkeley (2000)

Gastil, J., Levine P. (eds.): The deliberative democracy handbook. In: Strategies for Effective Civic Engagement in the Twenty-First Century. Jossey-Bass, Wiley, San Francisco, CA (2005)

Gerber, M.: Equal partners in dialogue? Participation equality in a transnational deliberative poll (Europolis). Polit. Stud. 63(1), 110-130 (2015). https://doi.org/10.1111/1467-9248.12183

Ghose, R., Pettygrove, M.: Urban community gardens as spaces of citizenship. Antipode 46(4), 1092-1112 (2014)

Glover, T., Shinew, K., Parry, D.: Association, sociability, and civic culture: the democratic effect of community gardening. Leisure Sci. 27(1), 75-92 (2005)

Gutmann, A., Thompson, D.: Why Deliberative Democracy?, pp. 3-7. Princeton University Press, Princeton and Oxford (2004)

Habermas, J.: The Theory of Communicative Action. Reason and the Rationalization of Society. Beacon Press, Boston (1984)

Han, S., Schenck-Hamlin, W., Schenck-Hamlin, D.: Inclusion, equality, and discourse quality in citizen deliberations on broadband. J. Public Deliberation 11(1), 3 (2015). https://www.publicdeliberation.net/ jpd/vol11/iss 1/art3

Isernia, P., Fishkin, J.: The EuroPolis Deliberative Poll. Eur. Union Polit. 3, 311-327 (2014)

Karolewski, I.P.: Pathologies of deliberation in the EU. Eur. Law J. 17(1), 66-79 (2011)

Karpowitz, C.F., Mansbridge, J.: The importance of dynamic updating in public deliberation. In: Gastil, J., Levine, P. (eds.) The Deliberative Democracy Handbook. Strategies for Effective Civic Engagement in the Twenty-First Century, pp. 237-253. Jossey-Bass, Wiley, San Francisco (2005)

Karpowitz, C.F., Raphael, C.: Introduction to deliberation, democracy, and civic forums: improving equality and publicity. Cambridge University Press, Cambridge (2014)

Karpowitz, C.F., Mendelberg, T., Shaker, L.: Gender inequality in deliberative participation. Am. Pol. Sci. Rev. 106(3), 533-547 (2012)

Karpowitz, C.F., Raphael, C., Hammond, A.S.: Deliberative democracy and inequality: two cheers for enclave deliberation among the disempowered. Polit. Soc. 37(4), 576-615 (2009)

Kuti, É.: Civil Europe-Civil Hungary. European House, Budapest (2008)

Lawrence, A.: Participatory assessment, monitoring and evaluation of biodiversity. In: Summary of the Web Discussion of ETFRN E-workshop on Participatory Monitoring and Evaluation of Biodiversity, 7-25 January (2002). https://www.researchgate.net/publication/237341897_Participatory_assessment_monit oring_and_evaluation_of_biodiversity. Accessed 25 April 2018

Lengyel, Gy.: From community forums to civic discussions. In: Lengyel, Gy. (ed.) Deliberative Methods in Local Society Research. The Kaposvar Experiences, pp. 9-17. Új Mandátum, Budapest (2009)

Lengyel, G., Ilonszki, G.: Hungary: between consolidated and simulated democracy. In: Best, H., Higley, J. (eds.) Democratic Elitism: New Theoretical and Comparative Perspectives, pp. 153-171. Brill, Leiden (2010)

Lengyel, G.: Know-how of organizing and studying civic discussions. In: Civic Dialogue, Civic Consultation, Civic Decision-preparation Forum, Civic Discussion, Policy Forum, Civic Preference Forum, Online Civic Dialogue, Online Civic Discussion. Manuscript (2016)

Lengyel, G., Göncz, B., Vépy-Schlemmer, É.: Temporary and lasting effects of a deliberative event: the Kaposvár experience. In: Coleman, S., Przybylska, A., Sintomer, Y. (eds.) Deliberation and Democracy: Innovative Processes and Institutions. Peter Lang Verlag, Frankfurt am Main (2015)

McKerrow, R.E.: Review of deliberation, democracy, and civic forums: improving equality and publicity by Christopher F. Karpowitz and Chad Raphael (New York, NY: Cambridge University Press, 2014). J. Public Deliberation 11(2), 9 (2015) 
McVey, D., Nash, R., Stansbie, P.: The motivations and experiences of community garden participants in Edinburgh. Scotland Reg. Stud. Reg. Sci. 5(1), 40-56 (2018)

Nettle, C.: Community Gardening as Social Action. Ashgate, Farnham (2014)

Ostrom, E.: Governing the Commons: The Evolution of Institutions for Collective Action. University Press, Cambridge (1990)

Ostrom, E.: A general framework for analyzing sustainability of social-ecological systems. Science 325(5939), 419-422 (2009)

Parker, P., Johansson, M.: The uses and abuses of Elinor Ostrom's concept of commons in urban theorizing. http://hdl.handle.net/2043/12212 (2011). Accessed 4 Jan 2016

Przeworski, A.: Deliberation and ideological domination. In: Elster, J. (ed.) Deliberative Democracy. Cambridge Studies in the Theory of Democracy, pp. 140-160. Cambridge University Press, Cambridge (1998)

Raphael, C., Karpowitz, C.F.: Good Publicity: the Legitimacy of Public Communication of Deliberation. Polit. Commun. 30(1), 17-41 (2013)

Renting, H., Schermer, M., Rossi, A.: Building food democracy: exploring civic food networks and newly emerging forms of food citizenship. Int. J. Sociol. Agric. Food 19(3), 289-307 (2012)

Russ, A., Peters, S.J., Krasney, M.E., Stedman, R.C.: Development of ecological place meaning in New York City. J. Environ. Educ. 46(2), 73-93 (2015)

Slocum, N.: Participatory method toolkit. A practitioner's manual. King Baudouin Foundation and the Flemish Institute for Science and Technology Assessment (viWTA) in collaboration with the United Nations University-Comparative Regional Integration Studies (UNU/CRIS) (2003). http://archive.unu. edu/hq/library/Collection/PDF_files/CRIS/PMT.pdf. Accessed 20 April 2018

Spilková, J.: Producing space, cultivating community: the story of Prague's new community gardens. Agric. Human Values 34(4), 887-897 (2017)

Steenbergen, M.R., Bächtiger, A., Spörndli, M., Steiner, J.: Measuring political deliberation: a Discourse Quality Index. Comp. Eur. Polit. 1(1), 21-48 (2003)

Steiner, J.: The Foundation of Deliberative Democracy. Empirical Research and Normative Implications. Cambridge University Press, Cambridge (2012)

Stitt-Gohdes, W.L., Crews, T.B.: The Delphi technique: a research strategy for career and technical education. J. Career Tech. Educ. 20, 55-67 (2004)

Stokes, S.: Pathologies of deliberation. In: Elster, J. (ed.) Deliberative Democracy. Cambridge Studies in the Theory of Democracy, pp. 123-139. Cambridge University Press, Cambridge (1998)

Sunstein, C.S.: The law of group polarization. In: Fishkin, J.S., Laslett, P. (eds.) Debating Deliberative Democracy, pp. 80-101. Blackwell Publishing, Oxford (2005)

Torres, A.C., Nadot, S., Prévot, A.-C.: Specificities of French community gardens as environmental stewardships. Ecol. Soc. 22(3), 1-13 (2017)

Tóth, L., Göncz, B.: Approches and experiences of previous deliberative polling. In: Lengyel, G. (ed.) Deliberative Methods in Local Society Research. The Kaposvar Experiences, pp. 21-27. Új Mandátum, Budapest (2009)

Wakeford, T.: A selection of methods used in deliberative and inclusionary processes. Particip. Learn. Action Notes 40, 29-31 (2001)

\section{Online sources}

http://www.charretteinstitute.org/

http://www.fao.org/docrep/006/T7838E/T7838E02.htm

http://www.ng.hu/Fold/2016/02/10/Kert-a-betondzsungelben

http://pangea.blog.hu/2014/12/17/kozossegi_kertekrol

https://participedia.net Methods

http://www.participatorymethods.org

https://www.participatorybudgeting.org

Publisher's Note Springer Nature remains neutral with regard to jurisdictional claims in published maps and institutional affiliations. 


\section{Affiliations}

\section{Fanni Bársony ${ }^{2}\left(\mathbb{0} \cdot\right.$ György Lengyel ${ }^{2}(1) \cdot$ Éva Perpék $^{1,2}$ (1)}

$\triangle$ Fanni Bársony

fanni.barsony@uni-corvinus.hu

György Lengyel

gyorgy.lengyel@uni-corvinus.hu

Éva Perpék

eva.perpek@uni-corvinus.hu

1 Centre for Social Sciences, Hungarian Academy of Sciences, Budapest, Hungary

2 Institute of Sociology and Social Policy, Corvinus University of Budapest, Budapest, Hungary 